\title{
Finite element method for analysis of stresses arising in the skull after external loading in cranio-orbital fractures
}

\author{
Metoda elementów skończonych do oceny naprężeń kości czaszki powstajq̨ych \\ po obciq̨żeniu zewnętrznym w złamaniach czaszkowo-oczodołowych
}

Hubert Wanyura', Piotr Kowalczyk², Maciej Bossak², Danuta Samolczyk-Wanyura', Zygmunt Stopa'

'Department of Cranio-Maxillofacial Surgery, Medical University of Warsaw

2Institute of Aviation, Warsaw

Neurologia i Neurochirurgia Polska 2012; 46, 4: 344-350

DOI: 10.5114/ninp.2012.30267

\begin{abstract}
Background and purpose: The craniofacial skeleton remains not fully recognised as far as its mechanical resistance properties are concerned. Heretofore, the only available information on the mechanism of cranial bone fractures came from clinical observations, since the clinical evaluation in a living individual is practically impossible. It seems crucial to implement computer methods of virtual research into clinical practice. Such methods, which have long been used in the technical sciences, may either confirm or disprove previous observations. The aim of the study was to identify the areas of stress concentrations caused by external loads, which can lead to cranio-orbital fractures (COF), by the finite element method (FEM).
\end{abstract}

Material and methods: For numerical analysis, a three-dimensional commercially available geometrical model of the skull was used which was imported into software of FEM. Computations were performed with ANSYS 12.1 Static Structural module. The loads were applied laterally to the frontal squama, the zygomatic process and partly to the upper orbital rim to locate dangerous concentration of stresses potentially resulting in $\mathrm{COF}$.

Results: Changes in the area of force application revealed differences in values, quality and the extent of the stress distribution. Depending on the area of force application the fol-

\section{Streszczenie}

Wstęp i cel pracy: Szkielet czaszkowo-twarzowy nie jest obszarem rozpoznanym do końca pod względem jego mechanicznych właściwości wytrzymałościowych. Informacje dotyczące mechanizmu złamań kości czaszki uzyskiwano dotychczas na podstawie pourazowych obserwacji, ponieważ w warunkach klinicznych ocena odporności szkieletu czaszkowo-twarzowego żywego człowieka na zewnętrzne obciążenia nie jest praktycznie możliwa. Słuszne wydaje się zatem wdrożenie do praktyki klinicznej komputerowych metod badań wirtualnych, od dawna stosowanych w technice, które mogą potwierdzić lub zanegować dotychczasowe obserwacje kliniczne. Celem pracy była ocena za pomocą metody elementów skończonych (MES) miejsc koncentracji maksymalnych naprężen sprowokowanych przez różnorodne zewnętrzno-boczne obciążenia szkieletu czaszkowo-twarzowego, które potencjalnie mogą prowadzić do złamania czaszkowo-oczodołowego (ZCO).

Materiał i metody: Do numerycznych analiz użyto trójwymiarowego, dostępnego komercyjnie geometrycznego modelu czaszki zaimportowanego do oprogramowania metody elementów skończonych. Do obliczeń wykorzystano moduł Static Structural komercyjnego oprogramowania ANSYS wersja 12.1. Obciążeniom poddano boczną powierzchnię łuski czołowej obejmująca guz czołowy, wyrostek jarzmowy

Correspondence address: Hubert Wanyura, Nowogrodzka St. 59, 02-006 Warsaw, Poland, phone: +48 225021239, fax: + 48 225022114, e-mail: kcst@kcs.amwaw.edu.pl

Received: 5.08.2011; accepted: 8.03.2012 
lowing parameters would change: the value and area of stresses characteristic of COF.

Conclusion: The distribution of stresses obtained in this study allowed definition of both the locations most vulnerable to fracture and sites from which fractures may originate or propagate.

Key words: cranio-orbital fractures, maximal stresses of skull, finite element method.

\section{Introduction}

Traumas of the skull affecting laterally the frontal squama provoke numerous fractures and dislocations of bones situated at the craniofacial interface. They are named cranio-orbital fractures (COF) $[1,2]$.

According to the clinical observations, $\mathrm{COF}$ are characterized by unilateral, asymmetric occurrence of cranioorbito-facial deformities that may result in severe neurological, ophthalmic, morphological, functional and aesthetic complications [1-3]. Trauma affecting the side of the frontal squama laterally (e.g. the frontal tuber, superior and lateral orbital rim) tends to produce a variety of fractures involving the cranial roof area (lateral surface of the frontal squama, temporal surface of the greater wing of the sphenoid bone and lateral rim and walls of the orbit), the orbital roof, the ethmoid and sphenoid roofs, and frequently the cranial surface of the greater wing of the sphenoid bone on the traumatized side as well as facial bones including the maxilla, the zygoma and the zygomatic arch.

The craniofacial skeleton is a structure that remains partly unrecognized as far as the characteristics of its mechanical endurance are concerned. Heretofore, the only information on the mechanics of cranial fractures that was available came from posttraumatic clinical observations since the evaluation of the craniofacial resistance to external loads and stresses in a living person is practically impossible in clinical conditions. Thus, it seems valid to implement computer-aided methods of simulation into clinical practice, which may confirm, or not, current clinical observations.

Following cranio-orbital trauma, a variety of fractures occur within the craniofacial skeleton affecting the region of the roof and the cranial base as well as the face kości czołowej i częściowo górny brzeg oczodołu, aby zlokalizować niebezpieczne naprężenia mogące prowokować ZCO.

Wyniki: Zmiany powierzchni przyłożenia siły ujawnity różnice w wartości, jakości i obszarze rozkładu naprężeń. W zależności od powierzchni przyłożenia siły zmieniały się wartości oraz obszary charakterystycznych dla ZCO naprężeńn.

Wnioski: Uzyskane w badaniach rozkłady naprężeń pozwoliły określić najbardziej narażone na zniszczenie obszary oraz miejsca mogące być początkiem pęknięć lub ich propagacji. Wyniki analizy numerycznej potwierdziły wieloletnie obserwacje kliniczne dotyczące ZCO.

Słowa kluczowe: złamania czaszkowo-oczodołowe, maksymalne naprężenia kości, metoda elementów skończonych.

on the same side. Thus, it is of primary importance to define anatomical areas where intracranial stresses manifest themselves.

According to the safety criteria concerning head injuries, and the head injury criterion (HIC) in particular, neurological complications and cranial fractures are defined. The safety criterion which defines the probability of bone fracture is the skull fracture criterion (SFC). It characterises the probability of cranial bone fracture due to deceleration, which is determined by gravitational acceleration. The deceleration of $124 \mathrm{~g}\left(\mathrm{~g}=9.8 \mathrm{~m} / \mathrm{s}^{2}\right)$ affecting the human head involves a $15 \%$ probability of a cranial fracture occurrence $[4,5]$. Deceleration of $200 \mathrm{~g}$ poses a real danger. For higher values, the probability of a cranial fracture and severe neurological sequelae is almost $100 \%[4,6]$.

The current results of virtual studies that employ the finite element method (FEM) to assess static resistance of the craniofacial skeleton to posttraumatic external loads are not only in concordance with long-term clinical observations which they have confirmed, but also allow one to predict the behaviour of bony fragments of the craniofacial skeleton under the influence of a variety of external loads. The FEM is the numerical method used for finding solutions for partial differential equations. In practice, the method is used for analyses of structural mechanics (displacements, strain, stress), heat flux, temperature distribution, fluid flux, etc. The method is mainly used in engineering and technical sciences, but is increasingly used also in biomedical engineering to evaluate mechanical behaviour of biological objects. Examples of this type of analysis are analyses of femur bone, brain trau$\mathrm{ma}$, tooth and its restoration. The analysis gives information about objects which can be difficult to achieve by 
experiments [7]. The FEM is often used to assess physical phenomena in the biomechanics of bone and soft tissue. Some studies use this method to estimate the forces and accelerations that act on the brain in the event of a collision of the head with a hard surface. Moreover, it was used to evaluate stresses in the cleft palate. A few studies exist that assessed the strength of selected areas of the craniofacial skeleton [5-8].

The aim of the study was to identify, using the FEM, areas of stress concentrations caused by external loads which can lead to cranio-orbital fractures (COF).

\section{Material and methods}

For numerical analysis, a three-dimensional geometrical model of the skull, which was described in the previous paper, was used [3]. In designing the geometry of the skull, special attention was paid to anatomical details, both external and internal ones. Static analysis by means of the FEM was performed assuming that the facial model is in its entirety built of isotropic material having properties of compact bone. To define the areas of the highest concentration of stresses, the Huber-Mises criterion of reduced stresses was used [9].

Computations were performed by means of commercially available FEM software ANSYS 12.1 Static Structural module (ANSYS Inc. Canonsburg, USA). Geometry of the skull was divided into 512446 finite tetrahedral elements not exceeding $3.5 \mathrm{~mm}$ (Fig. 1). The material from which the model was built was assumed to be homogeneous, isotropic, and linearly elastic [6]. Young's modulus of the material was assumed to be $18.0 \mathrm{GPa}$, with a Poisson's ratio of 0.22 [9-12].

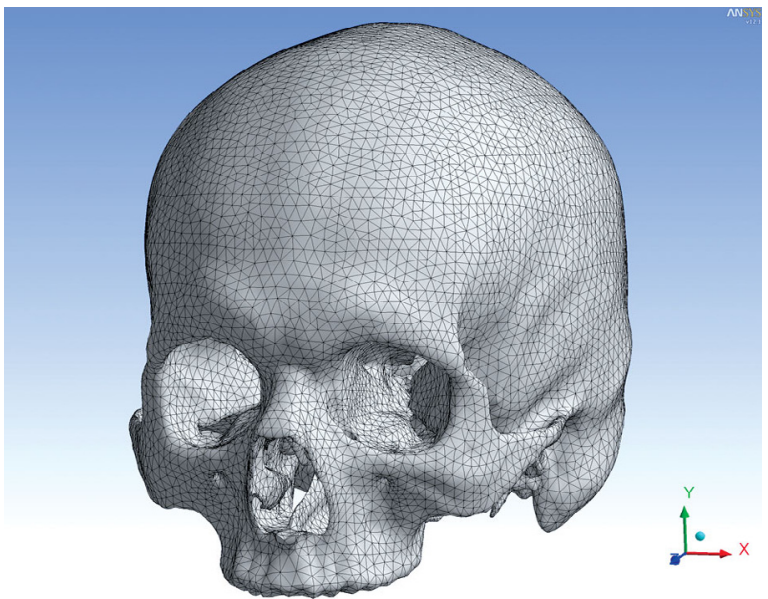

Fig. 1. Finite element model of the skull
The analysis aimed at revealing areas of concentration of the highest stresses after applying loads laterally to the frontal squama. It was assumed that the areas demonstrating the highest concentration of stresses would be identical to the sites where fractures occur.

\section{Loading the frontal squama laterally}

In order to define forces acting on cranial bones during impact, the deceleration value has to be multiplied by the mass of the object hitting the obstacle, in this case the mass of the head. It ranges from 3.2 to $5.4 \mathrm{~kg}$ (mean mass value $4.7 \mathrm{~kg}$ ) [4]. The force with which a head of medium mass impacts the obstacle with deceleration of $200 \mathrm{~g}$ is $9.4 \mathrm{kN}$; this value was accepted as the baseline for further analysis.

The loads affecting the frontal squama were applied to three different sites that differed in the area of force application. Three experiments were performed:

- Experiment I - 9.4 kN force applied in the vicinity of the frontal tuber to an area of $706.0 \mathrm{~mm}^{2}$ produced 13.3 MPa pressure (Fig. 2A),

- Experiment II - 9.4 kN force applied to an area of $1129.0 \mathrm{~mm}^{2}$ produced 8.3 MPa pressure (Fig. 3A),

- Experiment III - $9.4 \mathrm{kN}$ force applied to an area of $2958.0 \mathrm{~mm}^{2}$ produced 1.4 MPa pressure (Fig. 4A).

\section{Results}

The data are presented as Huber-Mises reduced stress distribution [9]. Depending on the value of pressure affecting the lateral surface of the frontal squama, the stress levels were different in each experiment. In order to maintain the clarity of experiments, for each one the same highest value of stresses was selected at 50.0 $\mathrm{MPa}$, and the loaded area was marked in red.

In each experiment, stresses differed both in values and distribution.

In Experiment I, the highest concentration of stresses (Fig. 2A) was observed at the site of force application, namely in the anatomical area of the frontal eminence. Additional stresses also slightly affected the orbital roof, concentrating immediately behind its upper rim. However, they did not extend beyond the sphenofrontal and frontoethmoid sutures superiorly or posteriorly (Fig. 2B). In turn, the posterior and the superior view of the inside of the cranial model revealed that the highest concentration of stresses arches around the frontal tuber posteriorly, to extend further to the orbital roof and the ethmoid roof 
including the ethmoid lamina, and then to the sphenoid roof on the same side. Relatively small areas of the highest stresses also concentrated on the small wing of the sphenoid bone immediately above the sphenoid fissure and around the optic canal (Fig. 2C).

In Experiment II, with the increase of the area of force application (1129 mm²; Fig. 3A), the highest concentration of stresses affected the temporal surface of the frontal squama, the temporal area of the greater wing of the sphenoid bone and the upper central orbital square mainly around its cone (Fig. 3B). At the same time (Fig. 3C), the marked concentration of stresses affected not only part of the ethmoid and orbital roof but also the entire sphenoid roof and additionally the cerebral area of the greater wing of the sphenoid bone. As opposed to Experiment I, the area of concentration of stresses characteristically affected a wider area of part of the orbital roof, the ethmoid roof, and the entire sphenoid roof (especially around the sphenoid fissure and the optic canal), and also the cerebral surface of the greater wing of the sphenoid. This observation confirms that such types of trauma may provoke bone damage not only in the frontocranial area but also the medial base of the cranial fossa (Fig. 3C).

In Experiment III, when the area of force application was $2958 \mathrm{~mm}^{2}$ (Fig. 4A), the concentration of stresses recorded in Experiments I and II did not occur in the area of the frontal tuber, the temporal surface of the frontal squama, or the temporal surface of the greater wing of the sphenoid. Alternatively, the stresses clearly concentrated in the area of the orbital cone (Fig. 4B).

Increasing the area of force application at the lateral aspect of the frontal squama to $1129.0 \mathrm{~mm}^{2}$ (Experiment II) revealed additional areas of stress concentration in the craniofacial skeleton. The highest concentration of stresses was recorded on the temporal surface of the frontal squama, the temporal surface of the greater wing of the sphenoid bone, and medially - in the upper orbital square in the vicinity of its cone. The highest concentration of stresses affected not only the orbital, ethmoid and sphenoid roofs intracranially, but also the cerebral surface of the greater wing of the sphenoid (mid-base of the cranial fossa) (Figs. 2-4).

\section{Discussion}

Numerical analysis performed in the three successive experiments demonstrated significant changes in the values of stresses and their distribution. The values of stresses depended on the area of force application to the lat-
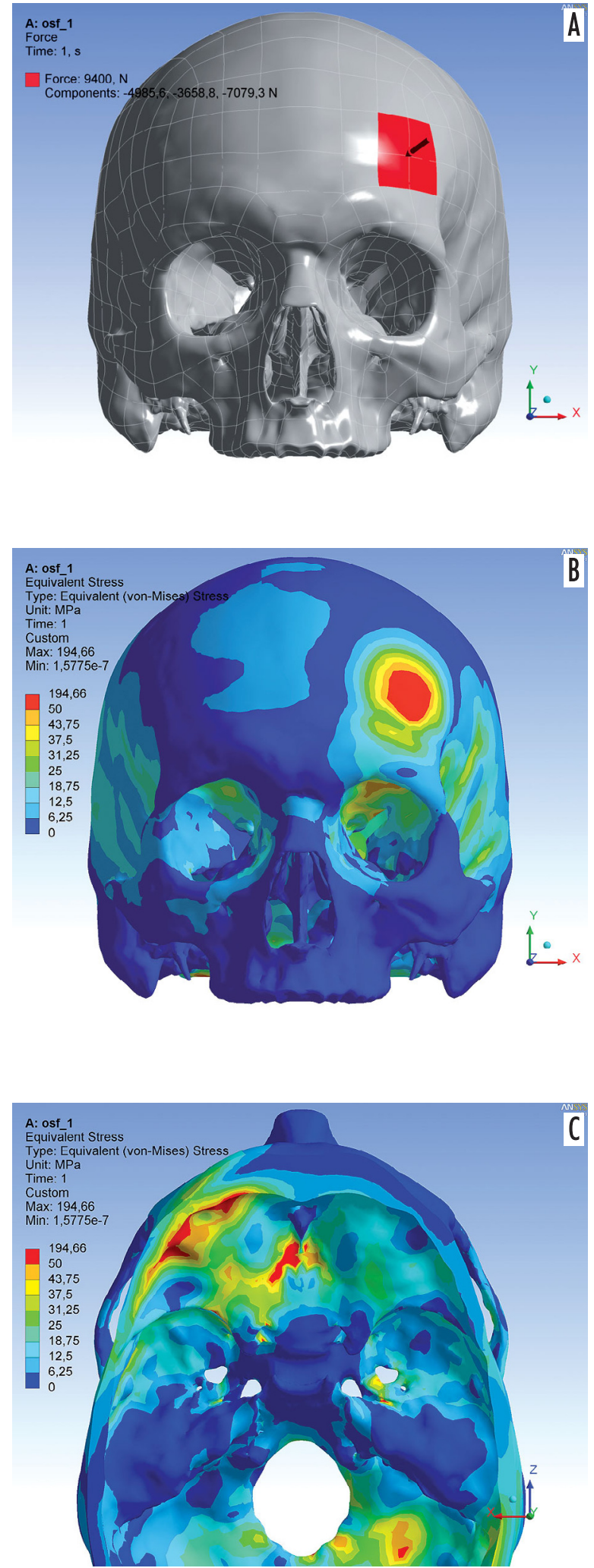

Fig. 2. Experiment I: (A) area $\left(706.0 \mathrm{~mm}^{2}\right)$ of force $(9.4 \mathrm{kN})$ application; $(B, C)$ concentration of stresses (red colour) on the skull after loading 

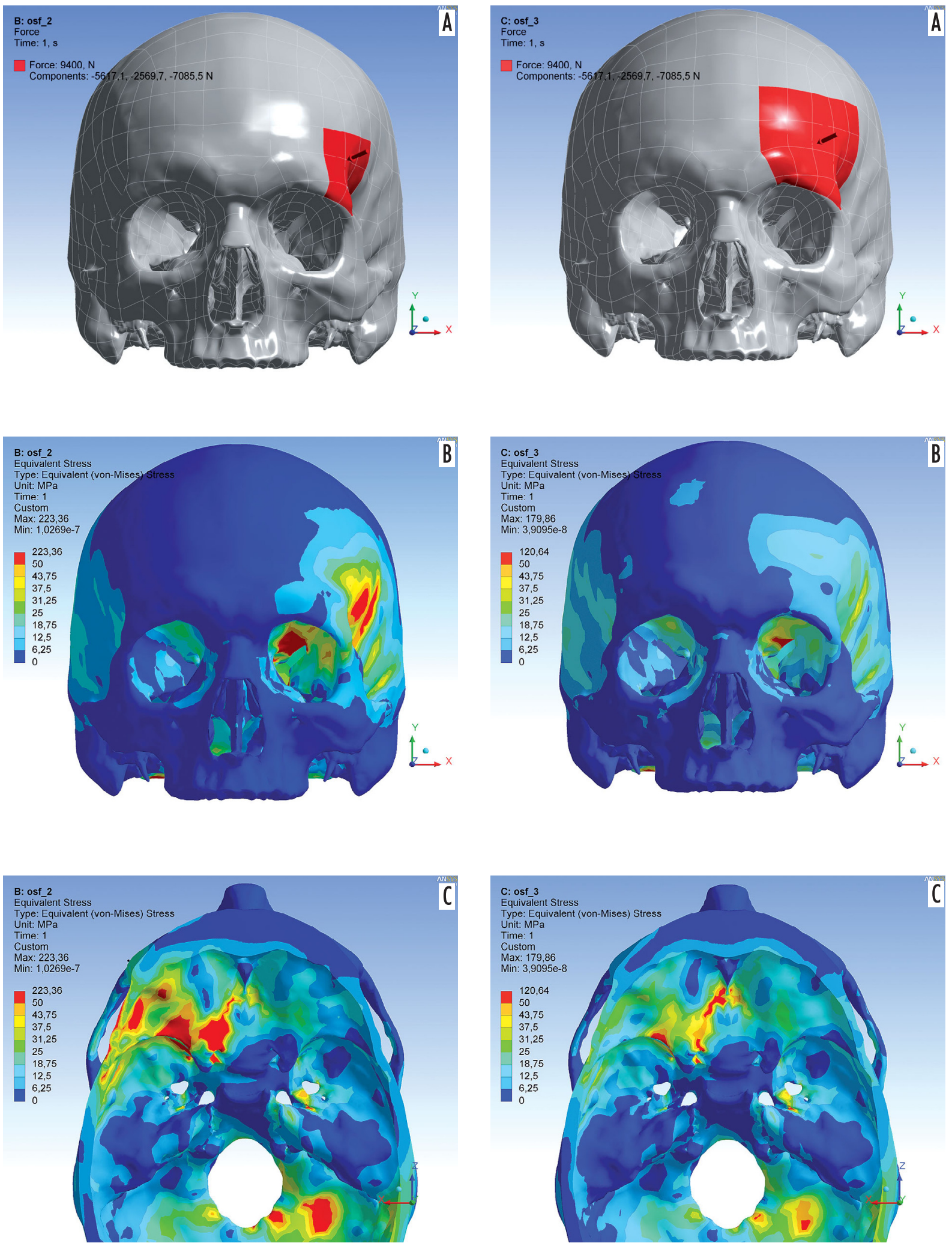

c

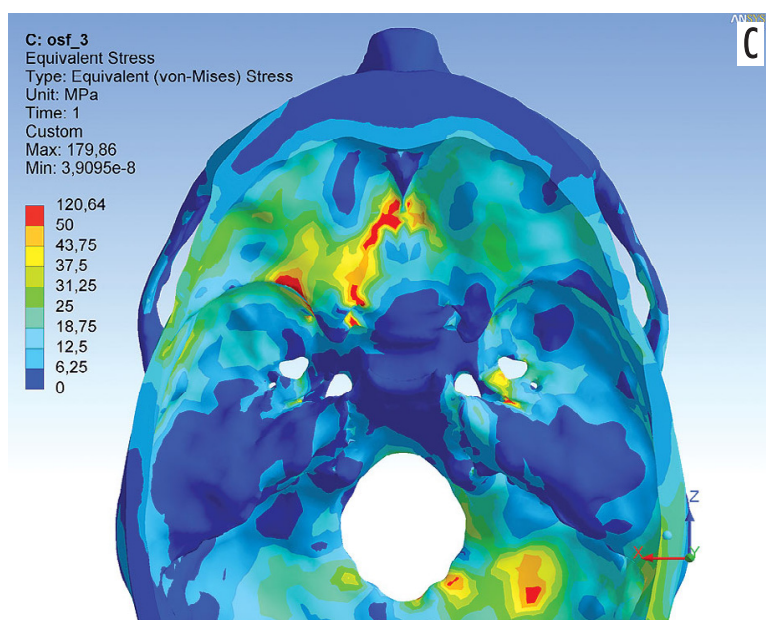

Fig. 3. Experiment II: (A) area $\left(1129.0 \mathrm{~mm}^{2}\right)$ of force $(9.4 \mathrm{kN})$ application; $(B, C)$ concentration of stresses (red colour) on the skull after loading

Fig. 4. Experiment III: (A) area $\left(2958.0 \mathrm{~mm}^{2}\right)$ of force $(9.4 \mathrm{kN})$ application; $(B, C)$ concentration of stresses (red colour) on the skull after loading 
eral aspect of the frontal squama. Although the highest concentration of stresses was confirmed at the base of the anterior cranial fossa in all the tests, the values of stresses did not decrease as the area of force application increased (9.4 $\mathrm{kN}$ in all the tests) but were different at all the above-mentioned bony elements of the cranial base.

When the area of force application was $2958.0 \mathrm{~mm}^{2}$ (Experiment III), the concentration of stresses did not reach the level recorded in Experiments I and II (the area of the frontal tuber, temporal squama or temporal surface of the greater wing of the sphenoid), though there was a marked concentration of stresses affecting the orbital cone and focusing on the ethmoid and sphenoid roofs, as in Experiment II. However, their area and distribution now differed in relation to previous experiments. When compared with Experiment II, a smaller area of stress concentration was observed around the optic canal and the lesser wing of the sphenoid bone.

After the cranial model is externally loaded with a homogeneous force of $9.4 \mathrm{kN}$, on the basis of the numerical analysis it can be calculated that the character of stress distribution changes relative to the area of force being applied to the frontal squama. Increasing the area of force application, as was the case in Experiment III, reduces the stresses occurring at the area of the cranial roof and base that are so characteristic of cranio-orbital fractures. This valuable observation may find practical application in the production of crash helmets, for example.

No papers have been found in the available literature evaluating the concentration of stresses in cranio-orbital fractures by means of the FEM. In the Polish literature, only two papers have been published that evaluate the suitability of the numerical analysis by means of the FEM to assess stresses occurring after trauma to the craniofacial skeleton $[4,13]$. In the first one, the FEM was used to evaluate the concentration of stresses occurring in low facial trauma and resulting in upper part of the face dislocations [13]. In the other one, which adopted a study model similar to the one discussed here, the authors discussed the maximal concentration of stresses occurring in the craniofacial skeleton after the frontal squama was centrally loaded [4].

The results of the numerical analysis were obtained virtually after loading the frontal squama of the cranial model externally at sites of varied areas with a homogeneous force - similar to the one that may clinically provoke fronto-orbitonasal fractures or cranio-orbital fractures. They confirmed significant changes in the values and distribution of maximal stresses. The values and distribution of maximal stresses observed on bony elements of the cranial roof and base, as well as on the face, depended on the site and area of force application in the frontal squama region. If the frontal squama was centrally loaded, then the highest concentration of stresses was observed in the whole anteroposterior area of the craniofacial column (the base of the anterior cranial fossa) [4]. If the frontal squama was loaded laterally, as was reported in this case, then the distribution of the maximal values of stresses was different from the one observed for cranioorbitonasal fractures. It partly affected the roof and the anterior and medial base of the cranial fossa, but only on the side of loading. No propagation of stresses was observed beyond the midline - opposite the site of trauma, as is observed in clinical practice.

Some limitations of the study should be noted. The calculations in this study are performed as static structural analyses. They do not define the propagation of the fracture lines (fractures) of the cranial bones. They only indicate stresses produced by pre-defined loads. The distribution of stresses thus obtained in this study allows definition of sites and regions most susceptible to damage from which fractures may originate and propagate.

\section{Conclusions}

1. The results of numerical analysis obtained in an anatomical area of the skull and face skeleton confirmed the long-term clinical observations characteristic for cranio-orbital fracture $[1,2]$.

2. Distribution of stresses in the skull after external loading depends on the area of the applied force. The most similar to the clinical features of cranio-orbital fractures was experiment II, when a $9.4 \mathrm{kN}$ force was applied to the frontal tuber to an area of $1129.0 \mathrm{~mm}^{2}$ and produced 8.3 MPa pressure.

\section{Disclosure}

Authors report no conflict of interest.

\section{References}

1. Wanyura H. Własne propozycje leczenia złamań oczodołu. Habilitation thesis. Medical University of Warsaw, Warsaw 1990.

2. Wanyura $\mathrm{H}$. Classification clinique et anatomopathologique des fractures de l'orbite. Rev Stomatol Chir Maxillofac 1989; 99: 80-87.

3. Jaracz K., Kozubski W. Quality of life after traumatic brain injury. Neurol Neurochir Pol 2008; 42: 525-535.

4. Wanyura H., Kowalczyk P., Raczko K., et al. Finite element analysis of external loads resulting in fronto-orbitonasal fractures. $C$ zas Stomat 2010; 63: 585-599. 
5. Yoganandan N., Pintar F.A. Biomechanics of temporo-parietal skull fracture. Clin Biomech 2004; 19: 225-239.

6. Marjoux D., Baumgartner D., Deck C., et al. Head injury prediction capability of the HIC, HIP, SIMon and ULP criteria. Accid Anal Prev 2008; 40: 1135-1148.

7. Boryor A., Geiger M., Hohmann A., et al. Stress distribution and displacement analysis during an intermaxillary disjunction a three-dimensional FEM study of a human skull. J Biomech 2008; 41: 376-382.

8. Kowalczyk P. Influence of the shape of the layers in photo-cured dental restorations on the shrinkage stress peaks - FEM study. Dental Materials 2009; 25: e83-e91.

9. Doblare M., Garcia J.M., Gomez M.J. Modeling bone tissue fracture and healing: a review. Engineering Fracture Mechanics 2004; 71: $1809-1840$

10. Li Z., Luo Y. Finite element study of correlation between intracranial pressure and external vibration responses of human head. Adv Theor Appl Mech 2010; 3: 139-149.

11. Yang J., Dai J. Simulation-based assessment of rear effect to ballistic helmet impact. Computer-Aided Design and Applications 2010; 7: 59-73.

12. Zong Z., Lee H.P., Lu C. A three-dimensional human head finite element model and power flow in a human head subject to impact loading. J Biomech 2006; 39: 284-292.

13. Samolczyk-Wanyura D., Wróblewski G. Numerical study of the upper-part of the face displacement using finite element method. Czas Stomat 2007; 60: 503-518. 